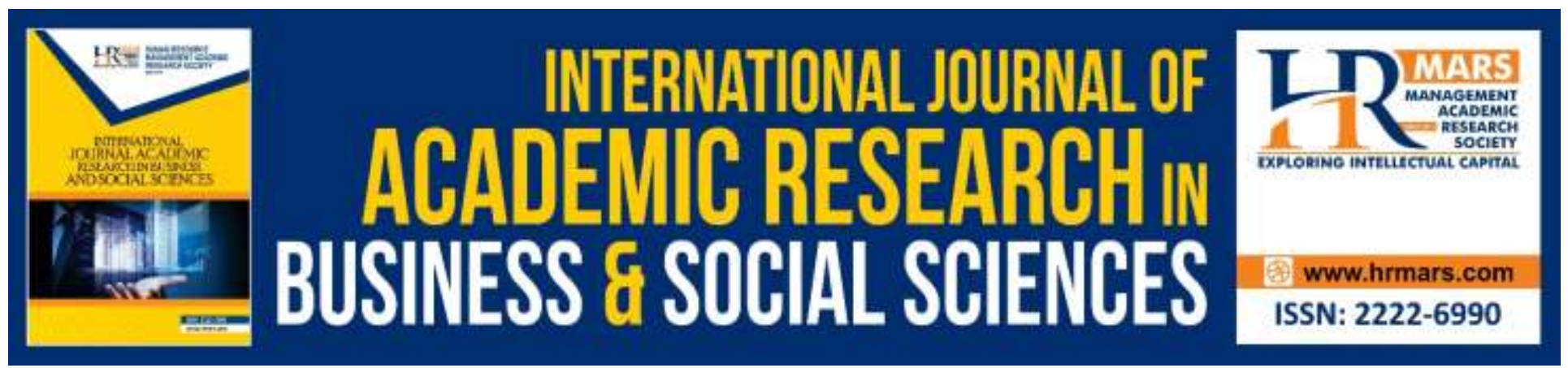

\title{
The Practice of Giving Guidance in the Context of Teacher Efficacy in Teaching of Grammar in Integrated Dini Curriculum (IDC) in Religious Schools
}

Farihah Hussain, Nik Mohd Rahimi Nik Yusoff, Maimun Aqsa Lubis, Rosni Samah

To Link this Article: http://dx.doi.org/10.6007/IJARBSS/v9-i1/5883 DOI: $10.6007 /$ IJARBSS/v9-i1/5883

Received: 26 Nov 2018, Revised: 14 Dec 2019, Accepted: 02 Jan 2019

Published Online: 23 Jan 2019

In-Text Citation: (Hussain, Yusoff, Lubis, \& Samah, 2019)

To Cite this Article: Hussain, F., Yusoff, N. M. R. N., Lubis, M. A., \& Samah, R. (2019). The Practice of Giving Guidance in the Context Of Teacher Efficacy in Teaching of Grammar In Integrated Dini Curriculum (Idc) In Religious Schools. International Journal of Academic Research Business and Social Sciences, 9(1), 1372-1378.

Copyright: (C) 2019 The Author(s)

Published by Human Resource Management Academic Research Society (www.hrmars.com)

This article is published under the Creative Commons Attribution (CC BY 4.0) license. Anyone may reproduce, distribute, translate and create derivative works of this article (for both commercial and non-commercial purposes), subject to full attribution to the original publication and authors. The full terms of this license may be seen

at: http://creativecommons.org/licences/by/4.0/legalcode

Vol. 9, No. 1, 2019, Pg. 1372 - 1378

http://hrmars.com/index.php/pages/detail/IJARBSS

JOURNAL HOMEPAGE

Full Terms \& Conditions of access and use can be found at http://hrmars.com/index.php/pages/detail/publication-ethics 


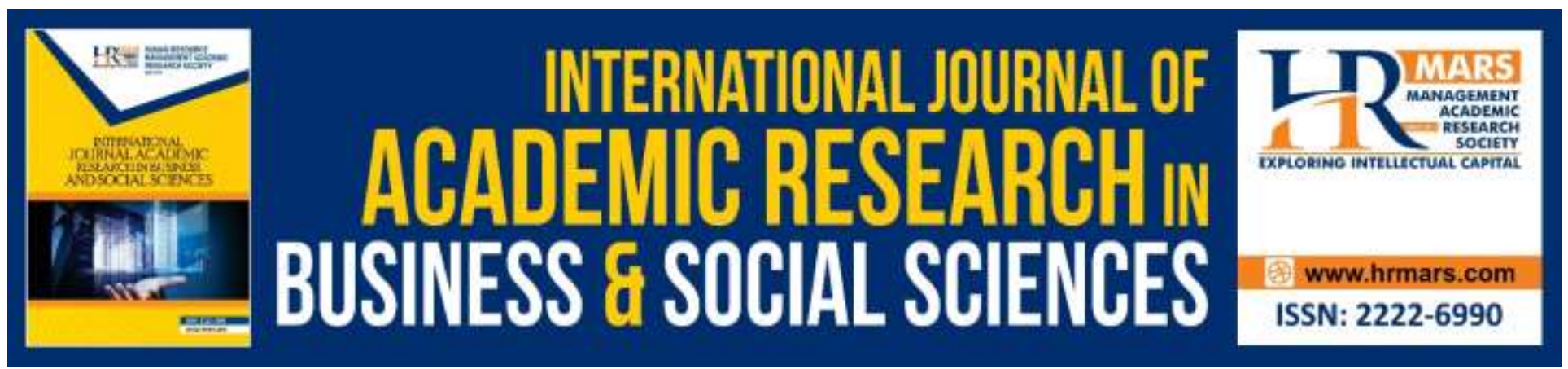

\title{
The Practice of Giving Guidance in the Context of Teacher Efficacy in Teaching of Grammar in Integrated Dini Curriculum (IDC) in Religious Schools
}

\author{
Farihah Hussain, Nik Mohd Rahimi Nik Yusoff (PM Dr), Maimun \\ Aqsa Lubis (PM Dr), Rosni Samah (Prof), \\ Universiti Kebangsaan Malaysia Bangi, Universiti Sains Islam Malaysia
}

\begin{abstract}
The aim of this research is to explore the practice of giving guidance in the context of teacher efficacy in teaching of grammar in Integrated Dini Curriculum (IDC) in religious schools. This is a qualitative research using interviews, observations and document analyses. This study involves seven research participants whom are five male teachers and two female teachers in Kedah. The themes were established using software-aided analysis of Atlas 8. Teacher guidance can be categorized into two aspects, which are guidance during and guidance after the teaching of grammar. The subtheme of guidance during teaching is spontaneous guidance. As for the subthemes for guidance after teaching are grammar clinics or workshops, tuitions and discussions on social media. Teachers' willingness to spend time shows they have efficacy (confidence) and high capability in educating and guiding students to understand the teaching of grammar.
\end{abstract}

Keyword: Teacher efficacy, grammar teaching, government supported religious schools

\section{Introduction}

Teachers' ability and confidence of themselves in performing their duties in teaching refers to teacher efficacy (Noornajihan Jaafar, 2015). Teacher Self-Efficacy model (Tschannen-Moran and Hoy, 1998) covers the aspects of teaching strategies, classroom management and student participation. In this research, the researchers explore the self-efficacy of teachers in terms of guidance in governmentaided religious schools (SABK) in the teaching of grammar in Kedah. This guidance is an additional aspect of the study in Noornajihan (2015). This study was carried out as per study recommendations in Azrien (2016) which mentions self-efficacy of teachers in SMKAs is simple while in SABKs the use of Arabic is greater compared to what is specified in the curriculum (MOE, 2015). Therefore, the need for skills and ability and confidence of the teachers is higher in SABK. 


\section{Background of the Research}

This is a part of a study conducted by the researchers on self-efficacy of grammar teachers in teaching grammar in an early stage of integrated curriculum religious school. In the context of this article, the discussion focuses on only one of the five objectives of the study. The researchers explore on selfefficacy of teachers in terms of guidance in teaching grammar of the Integrated Dini Curriculum (KBD) Religious School. Al-Ghazali's view about teaching is that the teacher is the one who is responsible to lead, guide, educate and train students to become servants of God who obey God and stay away from His prohibitions.

Teachers are entrusted as (a) substitute parents of students at the school, (b) the heirs of the prophets, (c) guides and counselors for religious students, (d) consultants, (e) motivators, (f) persons to understand the intellectual development of students and ( $g$ ) role models (Imam Ghazali (terjemahan Ismail Yakub), 1988). The concept introduced by Al-Ghazali is supported by (Noornajihan Jaafar \& Zetty Nurzuliana Rashed, 2015) the concept of 5M: teachers as murabbi, Muaddib, mursyid, propagator and mudarris.

In this study, the researchers focus on the task of teaching practice as a counselor in the context of teacher self-efficacy (ECG). High efficacy teachers will demonstrate necessary ability and capability and are willing to sacrifice their time to guide students who are weak in grammar.

\section{Problem Statement}

The issue of students' mastery in the learning process is often associated with teaching (Suhaidah Abdul Samat, Sofian Abdullah, \& Kamarulzaman Abdul Ghani, 2014). Therefore, one method of teaching is the academic guidance teacher. This is because the teacher's task is not only to teach but to lead towards academic excellence. In the context of this study, it refers to the teacher's guidance which is to clarify the content of textbooks, to motivate poor learners, and to create additional activities outside of school hours. Findings by (Noornajihan Jaafar \& Ab.Halim Tamuri, 2013) in his study that is related to EK teacher in the context of academic guidance and personal development is the GPI is higher than the level of teaching strategies, classroom management and student participation which are at very high levels. Therefore, this study is undertaken to explore the EK teacher in lughah al-Arabiah al-Muassiroh (LAM) in the teaching of grammar in the context of teacher's guidance.

\section{The Aim of this Research}

The aim of this research is to explore current practice of teacher-led instructions and after teaching grammar in the context of an Integrated Dini Curriculum (IDC) of teacher efficacy in religious schools in Kedah. The researchers of this study limit the guidance of teachers in the teaching of grammar to Form Three and Form Four students only in IDC in the subjects of al-Lughah al-Arabiah al-Mua'siroh (LAM).

\section{Research Methodology}

This study is a qualitative study using the case study method because the researchers are more keen to explore, interpret and gain deeper understanding and not to test a hypothesis (Width Othman 2015). The case study is a study that describes a small depth (Sabitha Marican, 2015) in real life 
INTERNATIONAL JOURNAL OF ACADEMIC RESEARCH IN BUSINESS AND SOCIAL SCIENCES Vol. 9, No. 1, Jan, 2019, E-ISSN: 2222-6990 @ 2019 HRMARS

(Cresswell, 2012). Stake explains that the case studies are the choices of cases to be investigated (Robert E. Stake, 1995). Cases reviewed in this study are on grammar teacher efficacy. This study uses a qualitative approach to examine interviews, observations and documents (Merriam 2009). Qualitative research is used to understand human problems through in-depth view of informants and conducted in a real and profound environment (Cresswell, 2012).

\section{Study Participants}

This study uses purposive sampling involving a total of seven teachers consisting of two female and five male teachers. The researchers interviewed and observed all study participants according to a predetermined schedule.

i. Data Collection Instrument

The researchers are the main instrument studies (Width Othman 2015). A set of interview protocol was prepared by the researchers. Researchers have gained validity of the interview protocol from three experts in the field. Afterwards, the researchers interviewed the study participants in religious schools in Kedah who taught grammar for Form Three and Form Four.

ii. Data Analysis

The researchers analyzed the data qualitatively with assistance from the Atlas software to produce themes that emerged from the transcripts of interviews and participant observation study reports conducted on teaching.

\section{Discussions Findings}

The results show that the teachers have the efficacy (confidence) in the teaching of grammar. The theme can be categorized into two parts: the guidance of teachers during lessons and after teaching. Evidence can be seen through the observation report GLAM6. "I went to students' tables to guide and monitor each of the students' activity (GLAM6/30012018 / P1). Most teachers feel comfortable to give immediate warning about errors made by students. This will help students. GLAM2 shows that the provision of time is used by teachers to give guidance directly to students. He said; in terms of guidance I feel I give my students sufficient time "(GLAM2/ 15012018 /TB1).

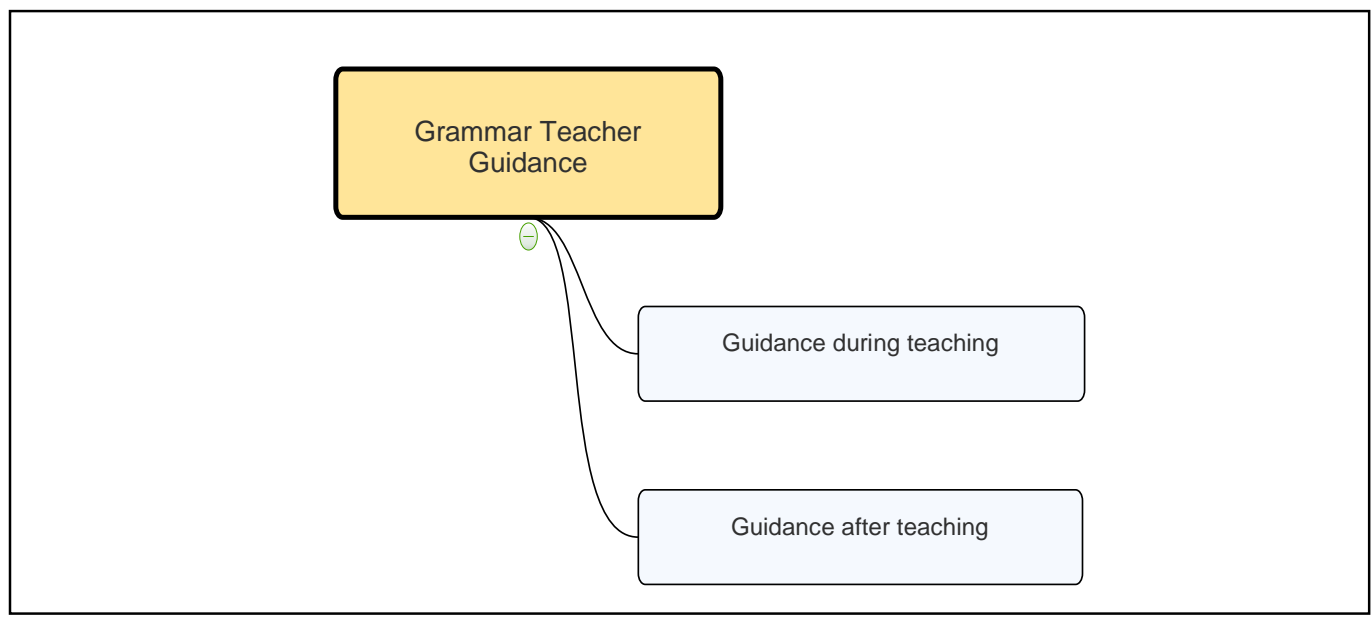

Figure 1: Themes found in grammar teaching. Source: researcher 2018 
INTERNATIONAL JOURNAL OF ACADEMIC RESEARCH IN BUSINESS AND SOCIAL SCIENCES Vol. 9, No. 1, Jan, 2019, E-ISSN: 2222-6990 @ 2019 HRMARS

As stated above in Figure 1 is the practice guidance in the context of grammar teachers' efficacy. The themes that appeared are divided into two; namely the guidance during lessons and the guidance after teaching. The researchers also categorized the guidance of teaching grammar in teaching as direct guidance or spontaneous. Teaching and coaching after the class were classified into grammar clinics, tuitions, and social networking sites. Figure 2 below illustrates the theme of the study after teaching grammar.

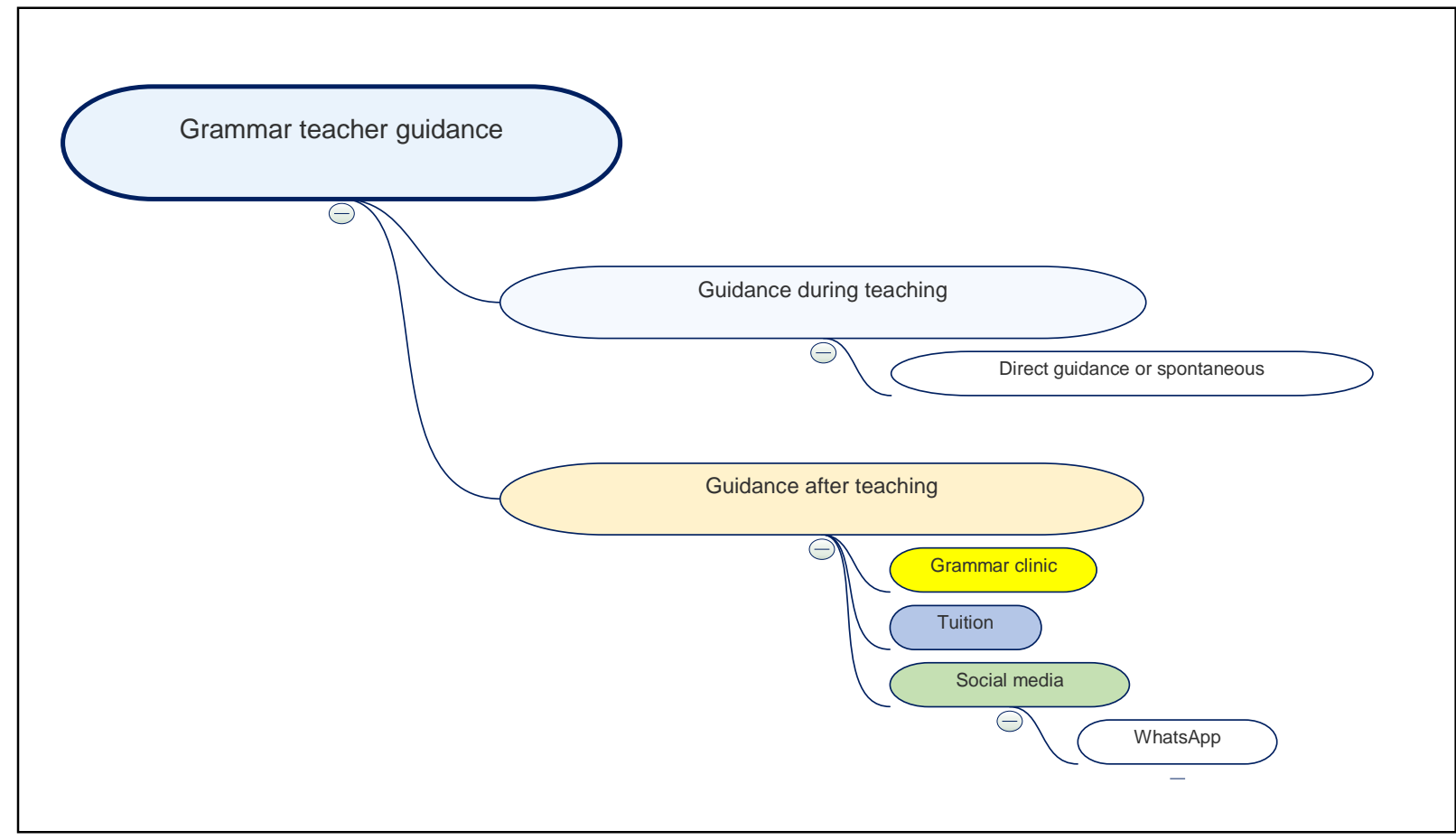

Figure 2: Breakdown of theme. Source: researcher 2018

In the context of this guidance, the teacher should apply the method of approach of divine revelation (Samah, 2009) to students. This approach means that there is affection between teachers and students, especially when providing guidance. This will make it easier for students to understand the difficult items. Sincerity will appear in teachers with high self-efficacy. Thus, the teaching will be more effective.

In addition, the efficacy of teachers will make them be able to help, to ease burden, to take the time to give guidance after school hours. They will spend their free time for students so that they will come to discuss and ask problems which arise after the lesson. Some evidence from the interview are;

"The clinic is useful because for example after the end of the teaching process, the students who do not understand the lesson will come and approach the teachers during recess and we will explain it to them bit by bit in order for them to really understand, that is usually my technique" (GLAM5 / 17012018 / TB1)

Study participant 5 (GLAM5) said that normally he would hold a grammar clinic after completing the grammar lesson whenever there are students who have difficulties in understanding the lesson. He provides an opportunity for students who do not quite understand, as individuals or groups. Similarly, 
INTERNATIONAL JOURNAL OF ACADEMIC RESEARCH IN BUSINESS AND SOCIAL SCIENCES

Vol. 9, No. 1, Jan, 2019, E-ISSN: 2222-6990 C 2019 HRMARS

study participant 8 (GLAM8), has workshop discussions for students who do not understand the teaching of grammar. GLAM8 also sometimes provides drills for them.

"The workshop is to discuss and to drill them with topical questions

(GLAM8 / 030518 / TB2)

Further evidence can be seen by the analysis of document (picture) teacher providing guidance to students. The sacrifice of these teachers shows that the teachers have the confidence and high spirits in themselves for the sake of their students' achievements. Discussions can happen anywhere. The view of GLAM5; "A teacher can discuss in the canteen, as long as the students can understand" (GLAM5 / 17012018 / TB1)

In addition, the guidance also suggests a high teaching efficacy in grammar teachers who are willing to take the time to discuss problems related to learning during the holidays or breaks through social networking sites such as WhatsApp, either personally or in a group. Understanding and achievement in the teaching of grammar is their priority.

\section{Research Implication}

The implications of the findings are teachers who teach Arabic grammar in particular are required to provide guidance immediately during or after teaching a lesson to improve understanding among the students. Based on observations of researchers on teaching, there are students who need to be guided because they lack a clear understanding when the training sessions are being conducted. Teacher's action of explaining spontaneously in the classroom has changed the situation to the students finally being able to understand. This suggests the practice or direct correction approach or spontaneous is more effective.

\section{Conclusion}

Guidance during lessons and after teaching proves that the ability and teacher's efficacy is high in the teaching of grammar. Teachers are willing to sacrifice time and energy in solving problems by counseling students in order to give better understanding and create better achievements in the teaching of grammar.

\section{Corresponding Author}

Farihah binti Hussain, Faculty of Education, universiti Kebangsaan Malaysia 43600 UKM Bangi, Selangor. Email: p88427@siswa.ukm.edu.my

\section{Attachment}

Analysis of documents related to the guidance of teachers after teaching grammar. 

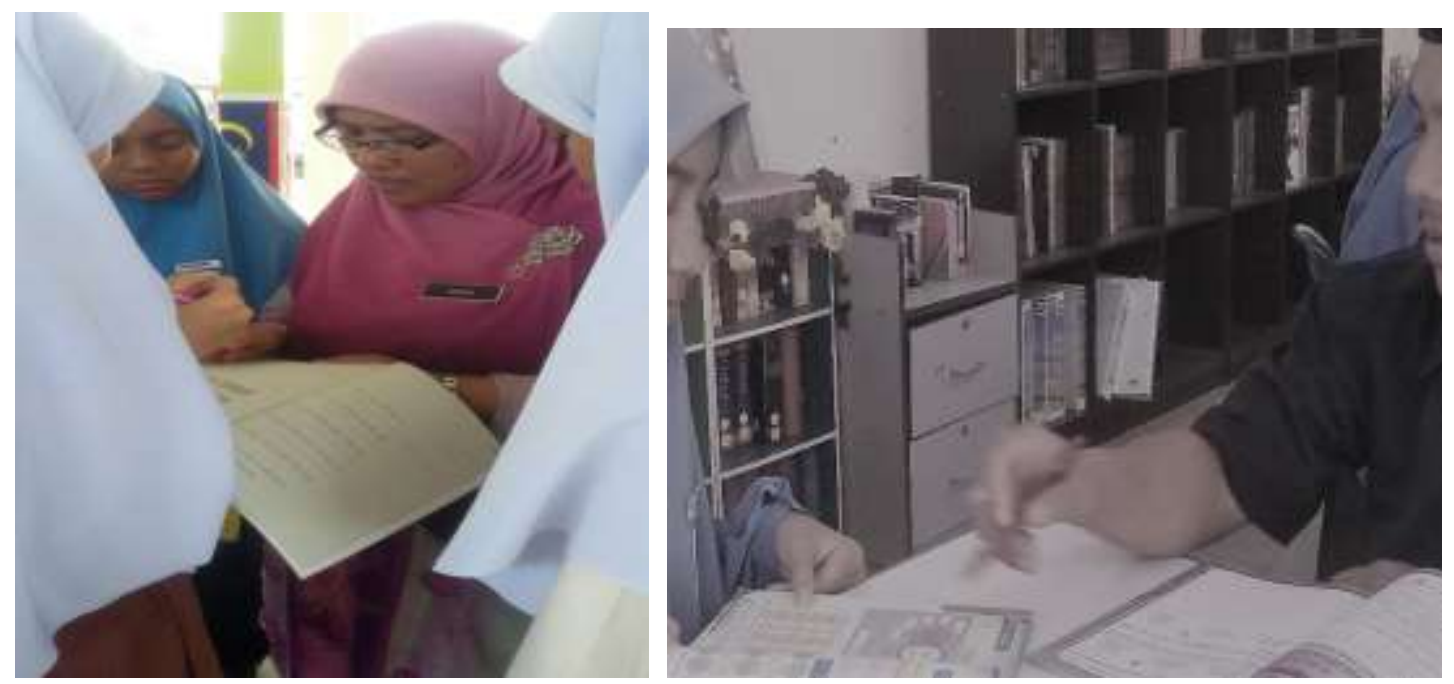

\section{References}

Cresswell, J. W. (2012). Educational Research: Planning, Conducting and Evaluating Quantitative and Qualitative Research. New York: Peason.

Hussain, F., Yusoff, N. M. R. N., Lubis, M. A., \& Samah, R. (2019). The Practice of Giving Guidance in the Context Of Teacher Efficacy in Teaching of Grammar In Integrated Dini Curriculum (Idc) In Religious Schools. International Journal of Academic Research Business and Social Sciences, 9(1), 1372-1378.

Imam Ghazali (terjemahan Ismail Yakub). (1988). Ihya Ulumiddin. Singapura: Pustaka nasional PTE LTD.

Noornajihan Jaafar. (2015). Pengaruh Efikasi Kendiri dan Faktor Persekitaran Terhadap Kualiti Guru Pendidikan Islam Sekolah Menengah Kebangsaan. Universiti Kebangsaan Malaysia.

Noornajihan Jaafar, \& Ab.Halim Tamuri. (2013). Hubungan Antara Efikasi Kendiri Dengan Kualiti Guru Pendidikan Islam Sekolah Menengah Kebangsaan Malaysia. Journal of Islamic and Arabic Education, 5(1), 41-60.

Noornajihan Jaafar, \& Zetty Nurzuliana Rashed. (2015). Model Kualiti Guru Pendidikan Islam Sebagai Murabbi. Tinta Artikulasi Membina Ummah (Vol. 1).

Sabitha Marican. (2015). Penyelidikan Sains Sosial.

Suhaidah Abdul Samat, Sofian Abdullah, \& Kamarulzaman Abdul Ghani. (2014). Penggunaan Strategi Pembelajaran Nahu Bahasa Arab Dalam Kalangan Pelajar Sekolah Menengah Agama di Negeri Perak. The Online Journal of Islamic Education, (Special Issue of ICIEd2014), 1-11. 